\title{
TECHNOLOGY PLATFORM FOR VENTURE CAPITAL INVESTMENTS IN INNOVATIONS IN THE CONDITIONS OF THE SIXTH TECHNOLOGICAL ORDER
}

\author{
Valery Vladimirovich Glushchenko *1四 \\ ${ }^{* 1}$ Professor, Project Activity Center, Moscow Polytechnic University, 38 Bolshaya Semyonovskaya \\ str., Moscow, 107023 Russia
}

DOI: https://doi.org/10.29121/ijetmr.v8.i3.2021.900

Article Citation: Valery

Vladimirovich Glushchenko. (2021).

TECHNOLOGY PLATFORM FOR

VENTURE CAPITAL INVESTMENTS

IN INNOVATIONS IN THE

CONDITIONS OF THE SIXTH

TECHNOLOGICAL ORDER.

International Journal of Engineering

Technologies and Management

Research, 8(3), 27-35.

https://doi.org/10.29121/ijetmr.v8

i3.2021.900

Published Date: 05 April 2021

Keywords:

Technology Platform

Venture Investment

Efficiency

Innovation

Technological Structure

Company

System

Management

Structure

Solution

\begin{abstract}
The subject of the article is the formation of a technological platform for venture investments in innovations in the conditions of the sixth technological mode; the object of the article is the sixth technological mode; the purpose of the article is the development of innovations in the conditions of the sixth technological mode; to achieve this goal, the following tasks are solved: research of the specifics of innovations in the conditions of the sixth technological mode, description of the construction of a technological platform for venture investments; research of factors of increasing the efficiency of venture investment, the methods of the article are venture investment, the theory of organizational structures, historical and logical analysis, synthesis, forecasting; the scientific novelty of the article is determined by the development of a methodology for designing a technological platform for venture investment in innovations in the conditions of the sixth technological order.
\end{abstract}

\section{INTRODUCTION}

In 2021, the development of the sixth technological order is observed. In the conditions of the new technological order, the intensity of innovation activity increases. In the sixth technological order, innovations become permanent [[1], p. $30-46 ; 2$, p. 3-29].

This creates a tendency to increase the number of subjects of innovative activity in the conditions of the sixth technological order. Therefore, the number of subjects of venture investment in innovative projects should also increase. 
Technology Platform for Venture Capital Investments in Innovations in the Conditions of The Sixth Technological Order

The hypothesis of this article is the assumption that in order to meet the demand for venture capital investments in the conditions of the sixth technological order, it is necessary to create technological platforms for venture investment in innovations.

The purpose of the article is the development of innovations in the conditions of the sixth technological order. To achieve this goal, the following tasks are solved:

- research on the specifics of innovation in the conditions of the sixth technological order;

- descriptions of building a technology platform for venture capital investments;

- research of factors for increasing the efficiency of venture investment.

The object of the article is the sixth technological order.

The subject of the article is the formation of a technological platform for venture investments in innovations in the conditions of the sixth technological order.

The formation of a new world economic system leads to changes not only in technology. Socio-economic relations in the economy are also changing [[2], p. 3-29].

The way to finance the development of innovations is venture investments [[3], p. 22-26]. There are several organizational forms of venture investment: first, such investors are venture funds [[4], p. 257-261]; second, business angels participate in the process of venture investment [[5], p.180-182]; third, venture investments are carried out by corporations [[6], p. 159-164].

An important problem of venture investment is the selection of innovative projects for such investments [[7], p. 186-189].

The development of methods for evaluating innovations makes it possible to ensure the economic efficiency of innovation programs. They believe that the existing number of venture funds is not enough for the development of innovations in the economy [[8], p. 2,7].

The main problem in the development of innovative entrepreneurship in developing countries can be called the lack of a developed infrastructure for such entrepreneurship [[9], p. 25-33].

This increases the risks in innovative entrepreneurship [[10], p. 2].

At the beginning of the 21st century, technology platforms are actively developing in Europe. The creation of such platforms is considered an important factor in the transition of the national economy to a new technological level [[11], p. 272-275].

The most important element of venture investment can be recognized as the adoption of a management decision on venture investment in a project [[10], p. 2; 12, p. 2]. The development of projects for the transition of national economic entities includes the development of venture investments [[13], p. 488-504].

The point of view is expressed that for the development of the venture capital investment market, it is necessary to develop the training of venture investors (business angels) in universities [[14], p.38-51].

The analysis shows that at the beginning of the 21st century, a system of venture capital investments is being formed in developing national economies. The current systems of venture financing for innovation in developing economies may have the following disadvantages:

- a relatively small number of venture capital funds compared to the scale of the economy [[8], p. 7];

- a relatively small number of individual venture investors (business angels). In Russia, the number of such business angels is from 500 to 1500 people;

- regional and industry business elites are not involved in the venture investment process;

- the infrastructure of the venture capital investment market is not sufficiently developed;

- there is a low level of mutual trust between venture investors and innovation creators;

- for inventors, the terms of venture investment are less attractive than in developed venture capital markets;

- there is no direction of higher education that provides training for venture investors and others.

In the process of development, it is necessary to reduce the shortcomings in the national systems of venture financing of innovations. At the same time, it is necessary to ensure not only a quantitative increase in the number of venture investors. We need to achieve qualitative changes in the system of institutional relations.

We will analyze what qualitative changes are needed in the systems of making venture investment decisions.

The decision-making system for venture investment in innovation depends on the organization of the activity of the subject of making this type of decision. 
Valery Vladimirovich Glushchenko

\section{METHOD}

At the beginning of the 21st century, there are two main types of investors in the venture capital market. The first type is an individual investor (business angel). This investor personally decides to invest in a certain innovative project. At the same time, the concept of alternative investments applies. An investor can only invest in one innovative project. This can create a lost profit for the investor. The disadvantage of this type of venture investment can be called restrictions on: the amount of individual financial resources; intellectual resources for the analysis of projects by such investors. At the same time, the limited intellectual capabilities of investors can influence the choice of projects. In turn, the choice of projects affects the economic efficiency and risks of decisions on venture investment.

The second most common type of investor is venture capital funds. These funds accumulate cash to invest in innovation. Then the funds received from investors are invested on behalf of the fund in innovative projects. At the same time, the decision to invest is made by the specialists of the venture fund (but not by the investor). The management decision-making system is determined by the internal administrative documents of such a fund. This may make the process of such an investment opaque to investors.

The development of innovations in the context of the formation of the sixth technological order requires: the expansion of the number of venture investors; the development of the infrastructure of venture investments; the creation of new types of venture investment institutions.

To increase the effectiveness of venture capital investments, it is necessary to develop the scientific foundations of such investment. Venture capital investment should be recognized as an independent type of financial services. The purpose of this financial service is to provide innovation with financial resources. These financial resources allow for the commercialization of innovations. Such investments are classified as high-risk (venture) investments.

Venture capital investment gives a new quality to innovation. Such an innovation becomes provided with the necessary financial resources. This creates the conditions for the development and commercialization of innovation. As a result of the commercialization of innovations, the needs of the economy for innovative development are met. At the same time, as a result of the commercialization of innovations, investors receive material benefits. This material benefit takes the form of an increase in the cost of capital invested in an innovative project.

Further development of the project approach methodology may include the synthesis of new organizational structures (architectures) of venture investment. These will be collective venture investment architectures. At the same time, individual investment decisions can be made by a specific venture investor (business angel). A new type of investment institution can be created for collective investment with individual investment decision-making. These are investment institutions with a distributed organizational architecture and a management decision-making system.

The technological platform for venture investment in innovation in the conditions of the sixth technological order will be called the association of entities that provide the process of investing in innovation.

At the beginning of the 21st century, technology platforms are actively developing in the European Union. However, the theoretical basis for creating such platforms has not yet been developed. Therefore, we will formulate some theoretical provisions for creating a venture investment platform in this article.

Technology platforms in the European Union are characterized, first of all, as a communication tool for its participants.

At the same time, the analysis allows us to say the following about technological platforms. Technology platforms are aimed at improving the efficiency of production of goods and services. Such platforms can bring together different categories of innovation actors. Such entities may include: corporations, universities, innovative firms, and individuals. This complicates the organizational structure of the technology platform. For this reason, the organizational structure of the technology platform is evolving into its organizational architecture. Combining diverse subjects of innovation into a single whole - a platform allows for more flexible consideration of the interests of the participants of such platforms. Within technology platforms, communications are a tool for improving production efficiency.

It can be said that technology platforms perform the following functions: to unite their participants in an innovative production system; to increase the efficiency of communication between platform participants; to collectively generate ideas; to coordinate the motives and interests of participants in the process of their joint activities; to perform an integrative function - the function of creating flexible organizational links between 
Technology Platform for Venture Capital Investments in Innovations in the Conditions of The Sixth Technological Order

innovation participants; to maximize the use of the creative potential of platform participants; to optimize the utilization of production capacities; the distribution function of the platforms and more.

The function of maximizing the use of the creative potential of platform participants is expressed in the fact that such a platform can include (under certain conditions) new carriers of intellectual potential. The resistance and inertia of the organizational structures of the technological platform becomes minimal.

As part of the capacity utilization optimization function, the technology platform allows you to flexibly change the volume of production activities. This opens up the possibility for such a platform to flexibly respond to market conditions. The distribution function of technology platforms is the fair distribution of remuneration based on the results of the commercialization of innovations.

This allows technology platforms to perform the following roles: optimizing the process of commercialization of innovations; better meeting the public and individual needs for innovation; optimizing the level of motivation of innovation participants.

The technology platform for venture investment in innovation has its own organizational and institutional aspects. Considering the technology platform in its institutional aspect, we can talk about such a platform as a new type of investment institutions.

The institute of venture financing of innovations will be called the system of relations in the process of financing innovations. These relations should ensure the development of venture investment in innovation activities. The institution of venture capital financing changes with the transition to a new technological structure. The reasons for the change in institutional relations in venture financing can be called:

- intensification of innovations in the sixth technological order;

- increased demand for venture capital investments due to an increase in the number of innovative projects in the sixth technological order;

- the post-industrial nature of innovation-the orientation of innovation to create new human needs.

Therefore, it is proposed to create a new type of investment institution. It will be a syndicated financial investment institution. This institution will have the form of a venture fund. Such a fund will take the form of a syndicate. This fund will carry out collective venture investment in innovative projects. This fund includes independent investors. An investor is an investing member of such a fund. Each of the fund's participants personally makes a decision about investing in an innovative project. Therefore, the syndicative investment fund (institute) will have a distributed system for making venture investment decisions. When creating such a new venture investment institute, the experience of the international company "Lloyd" can be used [[15],p.325; 16, p. 7-16].

From an organizational and legal point of view, such a venture institution can take the form of a technological platform [[11], p.272-275].

The technology of venture investment will be called a systematic combination of its elements: the organization of the fund's funds; the method of making investment decisions in the fund; the method of selecting investment objects-innovative projects; the method of creating a syndicate (pool) of investors; the method of distributing investment volumes among the members of the syndicate (pool) of investors; the method of accelerating an innovative project; the methods of obtaining additional funding for an innovative project; the qualification of participants in a venture investment fund.

The features of the venture investment platform can be called:

- all participants of the fund are divided into the following categories: investors; innovative brokers; appraisers of innovative projects; promoters (accelerators) of innovative projects;

- their financial resources are not centralized, they consist of independent funds of the funds of the investing members of the fund;

- a syndicate of investors is created to finance a certain innovative project. A syndicate (pool) of investors is a voluntary association of several investors to finance one innovative project;

- venture investment decisions are made by the investing members of the organization personally, and not by hired fund managers;

- creation of a syndicate (pool) of investors and preparation of an investment agreement is carried out by innovative brokers accredited at the venture investment platform; 
- the distribution of shares of venture capital investments in startups is made according to the results of the auction;

- each investing member of such a platform makes its own decision on financing or not financing a specific innovative project independently at its own risk and other.

Each venture investment platform independently approves the criteria for the selection and admission of its investing members.

The selection of investment objects (innovative projects) is carried out by innovative brokers. These brokers must be accredited with such a venture capital investment platform. The tasks of innovative brokers can be called: maintaining communication with the authors of innovative projects; evaluation of innovative projects; selection of innovative projects; creation of a syndicate (pool) of investors from among the investing members of the fund; preparation of an investment agreement; holding an auction for the distribution of investment shares in an innovative project, and more.

Each investing member of a venture fund may, on the basis of a contract, involve investment project appraisers accredited under this platform to justify their venture investment decision. The task of the investment project appraiser is to develop an independent objective assessment of the effectiveness of the innovation project. Such an assessment is important when making venture investment decisions. Participants of an innovative project (venture capital investment object) can attract innovative promoters (accelerators) to accelerate the promotion of the project. Innovative underwriters may be involved in the initial issue of securities by an innovative project.

At the same time, the considered venture investment platform may structurally consist of syndicates of investing members. Such syndicates of investors can be created on the following basis: joint financing of one innovative project; on the basis of their industry affiliation of investors; on the basis of investors ' belonging to a certain cluster, and others.

Identifying such syndicates of investing members based on their industry or cluster affiliation will allow you to more accurately predict and evaluate: the commercial prospects of an innovative project; the industry and individual risks of the project; the specifics of the implementation process of an innovative project; more effectively implement the results of the project; select more effective teams for project implementation, and more.

The monetary fund of the proposed venture investment platform (institute)will be segmented. It will consist of independent structural elements. Such elements will be the money funds of the investing (and in Lloyd's, insuring) members of this platform. Investing members of such a venture platform can be: individuals (business angels); legal entities (corporations, firms, venture capital funds). Investing members of such a venture platform should have a strong financial position. They must have: a positive reputation in society; a good image in business circles; enjoy the trust of the authors of innovations. Investing members do not have a license to invest. Investing members can be combined into syndicates. There may be syndicates based on the following investment factors: one innovation project; one region; one cluster; one branch of the economy. Such a venture platform is managed by the board of directors. This board of directors includes: heads of syndicates of a venture company; heads of pools of investors in large innovative projects; independent directors.

Innovative brokers present a specific innovative project to the members of the venture investment platform.

Innovative investment projects are presented to several (coalitions) investing members of the platform at once. The functions of investing members of the platform may be similar to those of subscribers (insurance members) in Lloyd's. A coalition of subscribers is formed by the key innovation broker of the innovation project. The key innovation broker acts on the basis of an agreement with the owners of the innovation project (investment object).

This key broker is involved in determining the necessary amount of funding for an innovative project. Such a key innovation broker can involve other brokers on the basis of agency agreements to work on the formation of a coalition of investing members.

An auction is held between the investing members who have agreed to join the syndicate. During such an auction, the investing members submit their bids. This application defines the size of the individual amount for the applicant's participation in the financing of a specific innovation project. If the total application (of all investing members) for the investment of an innovation project exceeds the amount requested by the innovation project, then a proportional reduction in the size of the individual investments of all syndicate investors is made. If the amount of applications is less than the amount requested by the project, the coalition of investors is invited to make a 
Technology Platform for Venture Capital Investments in Innovations in the Conditions of The Sixth Technological Order

proportional increase in their investment in this innovative project. In this case, the share of the investing members who refused (from increasing the volume of their investment) can be bought out by other members of the coalition.

Income (and equity) from investments in an innovative project, it is distributed in proportion to the investments made by the investing members.

When creating the proposed venture investment platform, the interest in the experience of making management decisions at Lloyd's is explained by the following. It was in the company "Lloyd" until the 1990s that individual management decision-making was practiced by its current (insurance) members. At the same time, the insurance process itself was of a collective nature. The risk for insurance was taken by several insurance members at the same time. It was a syndicate of insurers.

Factors that increase the cost-effectiveness of management decisions in such a distributed venture investment management system may include the following.

Increasing the internal motivation to make venture investments in specific venture investors. The reason for the growth of internal motivation may be the impact of the effect of "information asymmetry of the market". This effect is characterized by the following features: the market provides equal access to information; each of the investors subjectively believes that he has a greater (than other investors) amount of information. This effect is associated with the existence of implicit knowledge in innovation.

The formation of a "collective mind"in a syndicate of investors can also lead to an increase in the efficiency of syndicative investments. It is known that collective idea generation produces $70 \%$ more ideas than individual idea generation. Therefore, the general body of knowledge of the syndicate of investors is greater. This will increase the effectiveness of such venture investment solutions. The horizontal exchange of information between the members of such a syndicate can also be a factor in increasing the efficiency of investments. Such an exchange of information can facilitate more informed decision - making. This reduces the risk of investment decisions.

The exchange of views between interested investors in the process of making venture investment decisions contributes to the effectiveness of these decisions.

Individual investment decision - making leads to increased personal responsibility for the overall economic result of such an investment.

The creation of the infrastructure of the venture investment platform contributes to the efficiency of innovative projects, too.

The effectiveness of investment decisions increases the opportunity for each participating venture investor to use the services of consultants from various fields of knowledge and more.

Factors that reduce the risks of such venture investments may be:

- a more comprehensive study of the sources of project risk - factors and circumstances that can lead to a decrease in the planned effectiveness of the innovation project;

- a more in-depth study of the team and processes of the innovation project based on the "collective mind" of the investing members of such a venture investment fund;

- the creation of infrastructure and the use of specialists engaged in the risk assessment of innovative projects (innovative surveyors) as a whole or individual types of risks, and more.

\section{DISCUSSION}

The proposed venture investment platform can be a self-managed organization, for example, similar to the example of Lloyd's.

Such a venture investment platform can be characterized by a distributed management decision-making system. In the process of preparing an investment decision, all decisions can be divided into the following categories: decisions of venture (risk) investors in innovations (business angels); management decisions of innovative venture brokers; management decisions of appraisers of innovative projects (innovative surveyors); management decisions of innovative underwriters; management decisions of innovative promoters, etc.

We study the specifics of management investment decisions of these types. Let's consider the mechanism of influence of investment decisions on the economic efficiency of venture investment in innovative projects. A distributed system of venture decision-making can provide for two types of distribution: first, we are talking about an alternative distribution of the volume of venture investments among the participants of the pool of such investors; 
Secondly, we are talking about the distribution on the basis of functional specialization of certain types of decisions of venture capital investment entities (investor, broker, appraiser, underwriter, promoter).

In this paper, by the management investment decision, by analogy with the work [12, p. 8; 17, p. 60-75], we will understand the following. A management investment decision is a choice of one of the alternatives in the investment process. This decision takes place within the framework of the concept of alternative investments in financial management. This concept says the following: the investor invests his funds in one project; at the same time, the investor loses the opportunity to invest the same funds in another project. Therefore, the investment decision may be characterized by the investor's lost profit.

Making a management venture investment decision is an act of will. This act of will is associated with the performance of the venture investor's functions within the innovation process. The investment decision made determines the economic efficiency and risks of venture investments in innovations. The adoption of investment decisions by venture investors gives an imperative (mandatory, compelling) character to the entire investment management process. Making an investment decision creates the legal basis for the flow of funds in the economy. Making an investment decision is the central link in the development of the innovation process.

Management decisions of venture investors in innovation relate to the entire innovation project as a whole. Such decisions contain the following elements: the list of investment conditions; the volume of venture investments; the rights and obligations of the investor; the rights and obligations of the authors of the innovation project; the distribution of shares in the capital and profit of the project. The investment agreement should also contain other essential conditions for venture investments in innovations.

The management decisions of innovative venture brokers provide the basis for the innovative broker to submit a specific innovative project for consideration by venture investors. Such a decision of an innovation broker may include the following components: results of the analysis of the innovation use area; assessment of the competitiveness of the project product; comparative analysis of the advantages and disadvantages of a particular innovation project; recommended investment volume; project risk assessment; a list of potential venture investors who are recommended to offer participation in the venture financing of an innovative project and other information.

Management decisions of the evaluators of the effectiveness of innovative projects (innovative surveyors) are used by the investor when making decisions. Such an evaluation opinion increases the validity of investment decisions. Such a management decision of the project appraiser may reflect the independent expert opinion of such a specialist on the following issues: the projected economic efficiency of the project; the level of risks of the innovative project; the assessment of the risk of non-return of invested funds, and other data. Such data can be useful in preparing management decisions for venture investors.

The management decisions of innovative underwriters represent the choice of an alternative to "support or not support" the project with bank guarantees. A pool of underwriters is created if it is decided to conduct the initial issue of securities (IPO) of the project. Innovative underwriters make their decision to support a project based on such data. This can be data from a comparative analysis of the projected financial results of the two project options. This may be the results of analyzing the list of potential venture investors. The effectiveness of the project team is always taken into account. Information about the stage of development of the project, taking into account its life cycle, will also be important.

Management decisions of innovative promoters may reflect the choice of alternatives in a number of areas. First, the promoter can assess the need to further accelerate the process of implementing an innovative project. Secondly, the promoter may decide to implement the results of an innovative project in other sectors of the economy. As a result of multiplication of the results of innovative projects, there is an increase in the financial results of projects. At the same time, a well-known "scale effect" may occur. This creates a synergistic effect from the implementation of an innovative project.

Financing of an innovative project by a syndicate of investors increases the reliability of the venture investment process in the project. The reliability of syndicated financing is higher compared to the reliability of project financing by an individual business angel or a venture fund. This can have a positive impact on the development of innovation. Making investment decisions by a syndicate of investors will also help reduce the risks of innovative projects. The distributed nature of the management decision-making system leads to the study of the innovation project from different sides. The difference in views on the effectiveness of an innovation project is determined by the difference in the functions of the subjects of the venture investment process. This can also simultaneously increase the economic efficiency of innovative projects and reduce the risks of such projects. 
Improving the reliability of financing innovative projects will lead to an increase in the pace of development of the national economy. Successful implementation of innovative projects will create the basis for the development of the securities market. Successful innovative projects can become leaders in the high-tech segment of the securities market. This will increase the efficiency of the securities market as a tool for managing the socio-economic development of the country [18, p. 42-49]. This is important in a crisis.

All this allows us to draw a conclusion about the feasibility of creating such a technological platform for venture investment in practice. An important element of this platform should be a distributed system for making managerial venture investment decisions.

The effectiveness of such a platform can increase as a result of the development of strategies for the transition of industries and clusters of the economy to the sixth technological order [1, p. 30-46; 13, p. 488-504].

To train the staff of such technology platforms of venture investment, it is recommended to train such specialists in universities. The expansion of additional professional education in this area will also be useful for the development of venture investments [14, p. 38-51]. Active actors in the formation of such platforms can be: clusters; technology platforms; corporations; industry and regional banks; associations of stock market participants.

\section{CONCLUSION}

In this paper, it is proposed to create a new type of technology platforms. Their purpose will be to develop venture capital investments in innovative projects. The article analyzes the situation in the field of venture financing. The paper predicts an increase in demand for venture capital investments in the conditions of the sixth technological order and an increase in the pace of scientific and technological development. The article describes: the composition of the platform elements; the operating procedure of the technology platform for venture investment in innovations. The paper describes the functioning of a distributed system for making venture investment decisions. The factors of increasing the economic efficiency of a distributed system for making venture investment decisions in a technology platform for venture investments are studied. The article describes the positive impact of such a technological platform on the development of the economy and the securities market. It is proposed to train specialists in the field of venture capital investments in universities. This will help to reduce the intensity of the crisis.

\section{SOURCES OF FUNDING}

This research received no specific grant from any funding agency in the public, commercial, or not-for-profit sectors.

\section{CONFLICT OF INTEREST}

The author have declared that no competing interests exist.

\section{ACKNOWLEDGMENT}

None.

\section{REFERENCES}

[1] Glushchenko, V. V. (2021). Strategic planning of organizations ' transition to the sixth technological order in the national economy// International Journal of Engineering Science Technologies, 5(1), 30 - 46. DOI: https://doi.org/10.29121/IJOEST.v5.i1.2021.159

[2] Glazyev S. Yu. World economic structures in global economic development//Economics and Mathematical methods. 2016. Vol. 52. no. 2. p. 3-29.

[3] Aksenov V. L. Venture investments as a tool for financing innovations in Russia//In the collection: Management of innovation and investment activities: to the 80th anniversary of Professor Yuri Petrovich Anisimov. collection of materials of the All-Russian Anniversary Scientific and Practical Conference. Voronezh State Technical University. 2019. p. 22-26. 
[4] Zimina L. Yu., Titova N. S. Venture firms and venture funds//Alley of Science. 2019. Vol. 1. No. 1 (28). pp. 257 261.

[5] Markacheva A. S. Business angels as the main participants of the informal sector of venture investments//In the collection: The Future of Science-2015. Collection of scientific articles of the 3rd International Youth Scientific Conference: in 2 volumes. Executive editor Gorokhov A. A., 2015. pp. 180-182.

[6] Sukhanov A.V. Corporate venture investments in Russia: current state and prospects of development/ / Colloquium-journal. 2019. No. 14-6 (38). pp. 159-164.

[7] Markacheva A.S. The process of searching for projects for venture investments//In the collection: The Future of Science-2015. Collection of scientific articles of the 3rd International Youth Scientific Conference: in 2 volumes. Responsible editor Gorokhov A. A., 2015. pp. 186-189.

[8] Ostapyuk S. F., Filin S. A. Formation and evaluation of the effectiveness of scientific, technical and innovative programs. - M.: Publishing house of the firm "Blagovest-V", 2004. - 320 p.

[9] Glushchenko V. V., Glushchenko I. I. Methodological problems of the development of innovative entrepreneurship in high-tech mechanical engineering in Russia in the context of the global crisis// Problems of Mechanical Engineering and Automation, 2015, No. 1, pp. 25-33.

[10] Glushchenko V. V. Risks of innovation and investment activity in the context of globalization.Zheleznodorozhny, Moscow region: LLC SPC Krylia, 2006. - 230 p.

[11] Prikhodko I. I. Formation of technological platforms as a prerequisite for Russia's transition to the modern technological level//In the book: Organizational and economic problems of regional development in modern conditions. materials of the scientific and practical conference of young scientists, postgraduates and students. 2018. pp. 272-275.

[12] Glushchenko V. V., Glushchenko I. I. Development of a management solution. Forecasting-planning. Theory of experimental design. - Zheleznodorozhny, Moscow region, LLC SPC "Krylia", 2000. - 400 p.

[13] Glushchenko V. V. Scientific theory of technological structures and research of directions of its practical application//Bulletin of Science and Practice. 2020. Vol. 6 No. 4. Pp. 488-504.

[14] Glushchenko V. V. Program of continuing professional education on the "venture investor (business angel)"//Kazakhstan Science Journal. 2020. Vol. $3 . \quad$ No. $10 \quad$ (2). $\begin{array}{llllll}38 & \text { to } & 51 .\end{array}$ https://sciencejournal.press/sj/article/view/220/183.

[15] Glushchenko V. V. Risk Management. Insurance. - Zheleznodorozhny, Moscow region, SPC "Krylia" LLP, 1999. $-336 \mathrm{p}$.

[16] Galkina V., Kolpakova L. Activity of the London insurance company Lloyd in the insurance market//Ocean management. 2018. No. 1 (2). Pp. 7-16.

[17] Glushchenko V. V. , Sheveleva, I. A. Cooperative venture Fund for investment in technological innovation projects//Kazakhstan Science Journal. 2020. Vol. 3. № 11 (24). P. 60-75. https://sciencejournal.press/sj/article/view/221/184

(accessed 03.11.2020).

[18] Glushchenko V. V. Securities as a multi-functional tool for managing the socio-economic development of the state//Bulletin of GUU (State University of Management), Series "Financial Management", №1(9), 2006, pp. 42-49. 